\title{
Thomas Clarkson: um investigador incansável contra o tráfico negreiro
}

\author{
Thomas Clarkson: un Investigador Incansable contra el tráfico negrero \\ Thomas Clarrkson: an tireless investigator against slave trade
}

Mário Maestri*

Em memória de José Capela e Robert E. Conrad

\section{Resumo}

Ao concluir seus estudos superiores, o inglês Thomas Clarkson decidiu dedicar sua vida à denúncia e à luta pela abolição do tráfico de africanos escravizados pela Inglaterra. Na sua campanha antitráfico, ele se destacou por empreender uma vastíssima investigação com marinheiros, médicos ingleses, etc., dedicados àquele comércio. Autor de uma ampla bibliografia sobre o tema, apresentou em opúsculo, traduzido ao português em 1823, uma poderosa crítica ao comércio negreiro, antecipando conquistas historiográficas contemporâneas sobre ele. O presente artigo analisa essa sua célebre denúncia.

Palavras-chave: Tráfico escravista. Abolicionismo. África Negra.

\section{Introdução}

Thomas Clarkson nasceu em 1760, no seio de família de um pastor inglês. Após seguir com dedicação sua educação elementar e secundária, concluiu em Cambridge os estudos superiores, que o prepararam para o magistério religioso, que jamais exerceu. Ao redigir ensaio sobre a legalidade da escravidão para certame universitário, por ele vencido, enlevado pela situação com que se deparou, tomou a decisão de dedicar a sua vida à luta contra o tráfico de africanos escravizados, missão que compreendia igualmente como um dever religioso (CAPELA, 2002; CONRAD,

" Professor do Programa de Pós-Graduação em História da Universidade de Passo Fundo. E-mail: maestri@via-rs.net.

Recebido em 17/11/2014 - Aprovado em 25/03/2015 http://dx.doi.org/10.5335/hdtv.15n.1.5285 
1985; MARQUES, 1999; MENDES, 1977; RODRIGUES, 2005; RENAULT; DAGET, 1985, p. 67-126; REDIKER, 2011).

Clarkson deu um forte impulso ao movimento antitráfico, então em organização na Inglaterra, devido à sua enorme dedicação e às inovações de forma e conteúdo que introduziu na propaganda abolicionista. Para isso, procurou associar uma denúncia objetiva dos fatos à impugnação religiosa e moral tradicional do comércio de trabalhadores escravizados, desenvolveu extensa pesquisa sobre o tráfico tumbeiro nos portos ingleses, com destaque para Liverpool e Bristol, entrevistando milhares de marinheiros, comumente nos pubs por eles frequentados.

Na sua monumental coleta de informações, entrevistou, igualmente, médicos que haviam servido em tumbeiros e visitou navios atracados nos portos, prontos para partir ou chegados da África. Nessas visitas, obteve instrumentos de submissão de cativos, que passaram a ilustrar suas conferências e publicações. Portanto, fazia a denúncia dos maus tratos e apresentava as provas. Em 1788, conseguiu os planos de acomodação dos cativos do tumbeiro Brookes, com capacidade para 454 cativos, documento que causou fortíssima repercussão entre a opinião pública da época.

Ao visitar navios ligados ao tráfico negreiro, profundamente surpreso pela qualidade de produtos do artesanato africano que integravam o rol de bens mercantilizados, passou a divulgá-los como prova da excelência dos homens reduzidos à escravidão e da possibilidade do emprego desses na África em trabalhos dignos de homens livres. Tornou-se, portanto, também apóstolo da humanidade plena do africano, desqualificada pelos ideólogos do colonialismo, do comércio negreiro, do escravismo. Durante uma de suas múltiplas excursões aos portos ingleses, foi gravemente atacado por marinheiros a soldo dos armadores negreiros (PÉTRÉ-GRENOUILLEAU, 2004, p. 255).

Para dar a palavra ao africano, objeto do tráfico que denunciava em toda a sua abnormidade, Thomas Clarkson e seu irmão contribuíram para a divulgação das célebres memórias de Gustavus Vassa que, nascido possivelmente em 1745, no reino de Benin, na África, foi sequestrado, quase menino, com sua irmã, quando se encontravam em casa sozinhos. Após conhecer o cativeiro nas Índias Ocidentais, comprar a liberdade e viajar pelo mundo como marinheiro livre, Gustavus Vassa associou-se ao movimento antitráfico inglês, publicando suas memórias, em 1789, de estrondoso sucesso - Relato interessante da vida de Olaudah Equiano, ou Gustavus Vassa l'Africano (VASSA in ARMELLIN, 1975, p.8).

\section{Combate Permanente}

Após a aprovação da lei inglesa antitráfico de 1807, Thomas Clarkson dedicou-se com igual afinco ao controle da observância do fim do tráfico na Inglaterra e pela sua proibição em toda a Europa. Participou da fundação, em 1823, da Anti-Slavery Society, muito ativa na luta pela melhoria das condições de vida dos cativos e pela abolição gradual e, a seguir, plena da escravidão, que foi obtida na Inglaterra em 1833. Entre dezenas de livros e opúsculos, Thomas Clarkson escreveu, em 1808, uma história da abolição do 
comércio de escravos. Ele faleceu na Inglaterra, em 1846, aos 86 anos (WILSON, 1996).

Em 1823, era editada em Londres a tradução ao português de brochura de Thomas Clarkson, sob o sugestivo título Os gemidos dos africanos, por causa do tráfico da escravatu$r a$ : breve exposição das injúrias e dos horrores que acompanham este tráfico homicida. O livro, de 52 páginas, traduzido igualmente ao francês e ao espanhol, fora publicado, em 1821, em Londres, sob o título The cries of Africa to the inhabitants of Europe: or a survey of that bloody commerce called the slave trade, por Harvey, Darton \& Co. ${ }^{1}$

O livro de Thomas Clarkson era posto à disposição dos leitores do Brasil enquanto se lutava ainda, na Bahia, pela independência plena de Portugal. Nesses anos, o tráfico negreiro esmorecia no Brasil, devido à crise econômica, que vivia então a Europa, e, sobretudo, ao esgotamento da produção mineradora nas últimas décadas do século anterior. Crise da mineração que se dera sem emergir produto adaptado às condições da produção escravista colonial, que tivesse largo consumo externo.

Essa conjuntura singular levara José Bonifácio de Andrada e Silva a preparar, em 1823, uma "representação" sobre a abolição do tráfico e a reprodução natural dos cativos, jamais apresentada à Assembleia Constituinte e Legislativa, devido à sua dissolução. Nela, declarava-se a favor de emancipação gradual dos cativos; propunha o fim do tráfico negreiro, em três ou quatro anos, exigência dos ingleses; defendia medidas natalistas favorecendo a reprodução da prole escravizada - incentivos ao casamento; proteção e incentivos à maternidade, etc. (ANDRADE e SILVA, 1885). A crise da produção e do tráfico escravistas contribuiu igualmente para que dom Pedro acordasse com o governo inglês a abolição do tráfico transatlântico de cativos, às espaldas das classes escravistas do país (BETHELL, 1976; CONRAD, 1985).

Entretanto, muito logo, com o desenvolvimento da produção cafeicultora, primeiro nos serros dos arredores da corte, a seguir, no interior da província, no vale do rio Paraíba, a escravidão conheceu um vivíssimo impulso. A produção cafeicultora em expansão determinou que, após se esgotarem os estoques de trabalhadores negros feitorizados subexplorados, o tráfico transatlântico de africanos escravizados se reativasse como jamais ocorrera no Brasil (STEIN, 1961; GOULART, 1975, p. 95; KARASCH, 2000, p. 67-98; DA COSTA, 1982).

\section{Opúsculo subversivo}

Traduzido em português escorreito, praticamente sem gralhas, o opúsculo, como na edição inglesa, trazia como ilustração uma planta do navio negreiro inglês Brookes. $O$ exemplar que examinamos pertence ao Real Gabinete Português de Leitura, fundado em 1837, por comerciantes portugueses residentes no Rio de Janeiro, o principal centro do comércio de cativos do Brasil. O texto em inglês encontra-se à disposição em cópia fac-similar na rica coleção da Recovered Histories, que apresenta dezenas de publicações semelhantes (CLARKSON, 1823).

A obra Os gemidos dos africanos tem um prefácio e seis capítulos abordando as formas como os africanos eram reduzidos à 
escravidão; a impugnação do argumento da inferioridade do africano; os meios de transporte dos cativos, no interior e nas praias africanas até os navios negreiros; a terrível travessia transatlântica; a violação dos direitos humanos dos prisioneiros; a não razão das justificativas do comércio de homens e a falsidade da defesa do tráfico como meio de cristianização dos cativos.

$\mathrm{Na}$ época, os ideólogos escravistas acusavam os abolicionistas de exagerarem retoricamente os horrores do tráfico e da escravidão a fim de obterem mais facilmente adeptos para a causa que apontavam como falsa filantropia. Essa acusação tem sido comumente retomada por historiadores contemporâneos que propõem o desconhecimento objetivo da África Negra e do tráfico de cativos pelos abolicionistas e uma denúncia passional e romanceada de objetivos militantes.

Para ideólogos do tráfico negreiro daqueles anos e para boa parte da historiografia atual, o cativeiro nas Américas, nas mãos dos fazendeiros e outros escravizadores, seria apenas uma continuação, no outro lado do Atlântico, da escravidão já conhecida pelo africano em sua terra natal, nas mãos dos senhores autóctones. Proposta sustentada pela assimilação abusiva entre a escravidão colonial americana e as variadas formas semiservis de dominação do continente negro, como veremos com mais vagar (MEILLASSOUX, 1975, 1977, p. 61-88; MIERS; KOPYTOFF, 1977; GODELIER, 1976; CRUMMEY; STEWART, 1981; LOVEJOY, 1983).

Procurando a mais fidedigna resposta possível às apologias negreiras, em seu opúsculo, Thomas Clarkson prima pela contenção das análises e pela preocupação em apoiar suas denúncias em informação fiável. Como vimos, os dados que apresentava haviam sido obtidos durante longos anos de cuidadoso e sistemático interrogatório de marinheiros e médicos envolvidos no tráfico; quando de visita a navios tumbeiros; em documentação original, etc. O que empresta ao opúsculo um tom de quase relatório histórico-científico. Em sua narrativa, raramente deixava transparecer em crítica mais arrebatada o páthos que envolvia a discussão.

\section{0 coração da África Negra}

Por meio de sua démarche de forte cunho empirista, Thomas Clarkson apresenta aos seus leitores panoramas de profundo sentido materialista sobre a experiência negreira. Tal procedimento permite que aborde e desvele, em seus nexos profundos, muitas tendências essenciais do tráfico de cativos e das apologias construídas em sua defesa. Nesse sentido, antecipa, no geral, as conclusões obtidas mais de um século após sua investigação pela moderna historiografia especializada sobre o tráfico e a escravidão americana.

As palavras iniciais do Prefácio ao leitor são empregadas na apresentação e na discussão das duas principais fontes literárias em que o autor apoia sua narrativa: As memórias do "célebre viajante inglês (sic) Mungo Park" e o Livro de evidências, publicado por ordem do parlamento inglês.

De 1795 a 1797, enviado pela African Association, Mungo Park (1711-1806) viajou até as margens do rio Níger, descrevendo em um belo e pouco preconceituoso relato uma África que, por décadas, nenhum ou- 
tro europeu vira ou veria. Salvo engano, o jovem médico escocês foi o único viajante europeu a penetrar tão profundamente no coração do Sudão Ocidental, antes do fim do tráfico afro-europeu de homens e mulheres nessa região (PARK, 1980, p. 59-64.).

Em seu relato, Mungo Park registrou que essas paragens apresentavam um "quadro de opulência e de civilização" que não "esperava encontrar no centro da África". Em verdade, ao contrário do que ocorria, por exemplo, nas longas costas do Brasil, onde a rica e verdejante Mata Atlântica litorânea dava lugar a sertões comumente áridos e despovoados, as costas atlânticas da África, comumente insalubres e pouco habitadas, sobretudo da faixa sudanesa, abriam-se, no geral, para regiões férteis, salubres e densamente povoadas (MAESTRI, 2013).

Mungo Park realizou boa parte de sua viagem em direção ao interior africano em companhia de comerciantes africanos dedicados ao comércio de homens e de mercadorias. Descreveu em detalhes a arrastada e dolorosa viagem dos cativos dos sertões em direção ao litoral, mantidos sob o poder do látego, dos punhais e das armas de fogo de seus escravizadores. Construiu, assim, um dos mais importantes e fiáveis documentos sobre a organização do tráfico no interior do continente, em sua época (PARK, 1980, p. 206; MAESTRI, 1983, p. 59-64).

\section{Enquete geral}

Como explica Thomas Clarkson, o $\mathrm{Li}$ vro das evidências recolheu o "depoimento de muitas pessoas que tinham estado em África, umas como viajantes e outras implicadas no tráfico da escravatura". Depoimentos "tomados por uma comissão da Casa dos Comuns" (Parlamento britânico) que por três anos registrou essa informação, obtida, comumente, de "indivíduos interessados na continuação" (CLARKSON, 1823, p. 6) do tráfico, como explica o autor. Entre os depoentes, havia capitães de navios negreiros, comerciantes de cativos, entre outros.

A consciente procura de objetividade e a contenção do autor permitiram que a moderna historiografia do tráfico corroborasse os grandes cenários apresentados em Os gemidos dos africanos. Atualmente, estima-se, no geral, a mortalidade dos cativos embarcados no século XVIII em 20\%, com uma redução para $10 \%$ no século seguinte, números já então avançados pelo autor. O que era uma verdadeira mortandade, considerando-se a juventude e a saúde dos cativos, além da brevidade média da viagem (MAESTRI, 2002).

Valorizava a versão portuguesa do livro o fato de que Thomas Clarkson lançava mão essencialmente de exemplos ingleses. $\mathrm{O}$ que dificultava a galvanização nacionalista da opinião pública das nações escravistas de língua portuguesa, caso a crítica fosse dirigida essencialmente contra o comércio tumbeiro de Portugal e do Brasil. Para o autor, a nacionalidade do negreiro pouco importava na determinação das suas práticas. Visão que se tem consolidado nas últimas décadas entre os especialistas, ainda que a partir de razões diversas da apresentada por Thomas Clarkson:

Não altera os casos se o tráfico é feito por franceses, holandeses, portugueses [...]; o resultado há de ser o mesmo: a natureza humana é semelhante em todos os países do Universo (CLARKSON, 1823, p. 4). 
Folga dizer que, mesmo se por questões táticas, se a crítica fosse voltada, sobretudo, contra o tráfico, Thomas Clarkson não fazia a menor ilusão sobre as condições dos trabalhadores escravizados na América, que combateria, a seguir, com o mesmo afinco.

[...] a narração que nos propomos oferecer, diz só respeito ao que comumente se chama o tráfico na Costa da África; e não abrange os tormentos que depois se fazem padecer as tristes vítimas nas Colônias (CLARKSON, 1823, p. 4).

Nesse momento, aprovado o fim do tráfico inglês, o autor e os abolicionistas britânicos dedicavam-se já à luta pela emancipação dos cativos das colônias britânicas, batalha vitoriosa em 1833 .

\section{Fontes da escravidão}

A narrativa refere-se com pertinência às principais fontes produtoras de cativos na África: apresamentos individuais; razias e expedições militares, na costa e no interior do continente negro; a justiça africana; o endividamento (CANOT, 1947, p. 284-285; PARK, 1980, p. 284-293; MENDES, 1977, p. 39-42; ROCHA, 1992, p. 49.). Uma descrição circunstanciada que desemboca na crítica arguta da explicação escravista de que os negreiros apenas compravam cativos produzidos pela violência natural da sociedade africana, salvando-os assim da morte. $\mathrm{Ou}$ seja, os cativos seriam presas justas.

Pessoas interessadas em tão desumano tráfico, para se desculparem, tem feito espalhar, que as guerras de África tem mais origem no caráter feroz dos naturais, do que no desejo de fazer prisioneiros para vender [...].
Vender, logicamente, sobretudo, para os comerciantes europeus da costa. Uma tese abraçada parcialmente por não poucos africanistas contemporâneos, que defendem a pré-existência da escravidão no continente negro, como já assinalado.

Mesmo concedendo que alguns dos infelizes transportados pelos tumbeiros fossem produzidos pelas disputas endógenas às sociedades africanas, Clarkson desenvolve fina análise demonstrando que a produção ininterrupta de cativos, pelos próprios africanos, para obter os valorizados produtos do tráfico, era apoiada e incentivada por todos os meios pelos negreiros (CANOT, 1947, p. 4.). Uma dinâmica perversa precisada, em suas linhas gerais, pelo clássico estudo de José Capela, Escravatura: a empresa de saque, o abolicionismo (1810-1875) (CAPELA, 1974; 1978).

\section{Responsabilidade africana}

Ao apresentar a justiça africana costumeira como outra fonte de redução do africano livre ao cativeiro, Thomas Clarkson refere-se igualmente à perversão e à potenciação do poder comunitário pelos segmentos dominantes africanos envolvidos pelo tráfico:

[...] quando este Continente começou a ser visitado por europeus, os castigos públicos eram mui leves, e proporcionados aos crimes cometidos [...]: porém, desde aquele tempo, a jurisprudência d'África tem-se acomodado às exigências do Tráfico da Escravatura; $[. .$.$] hoje em dia, a menor ofensa$ que se comete é punida com escravidão. $O$ crime imaginário de feitiçaria é o artigo de renda mais produtivo, que tem os chefes daqueles povos (CLARKSON, 1823, p. 4.). 
Thomas Clarkson lembra pertinentemente que as razias e as guerras motivadas pelo tráfico, com o sequestro dos homens mais produtivos e a destruição das plantações, eram, em última instância, algumas das grandes responsáveis pela própria venda de parentes pelos patriarcas, ou pela autovenda do africano como cativo, devido à fome. $\mathrm{O}$ autor assinala que, após os ataques escravizadores, não só as aldeias eram muitas vezes inteiramente destruídas, mas também os campos de arroz que lhes pertenciam. Disto resultava que as poucas miseráveis pessoas que escapavam à escravidão ou à morte, fugindo para os matos não achavam com o que sustentar-se quando voltavam as suas casas.

$\mathrm{Na}$ África Central, a introdução da plantação da mandioca, trazida da América do Sul pelos lusitanos, teria se desenvolvido, em boa parte, devido à capacidade dessa planta. A mandioca, "resistente à seca, aos parasitas", podia permanecer sob a terra, por até um ano e meio, à espera de ser colhida (MAESTRI, 1978, p. 85-87). Tal qualidade garantia alimentação às populações africanas após as razias escravizadoras que se abatiam sistematicamente sobre aquelas regiões, dispersando os que alcançavam a fugir, desorganizando a vida produtiva, motivando miséria e fome, mesmo depois de passados meses dos ataques (VANSINA, 1965, p. 147).

A mesma crítica é feita à escravidão por dívidas, que propõe ter sido utilizada pelos negreiros europeus e africanos como meio de redução sistemática de homens e mulheres livres ao cativeiro. Na crítica dos malefícios motivados à África Negra pelo tráfico europeu, defende - não totalmente sem razão - que o maior desenvolvimento e a maior civilização do interior do continente em relação ao litoral deveria-se, também, ao maior ou menor contato com os europeus escravizadores. Tratava-se de verdadeira e implacável inversão da proposta apologética da obra civilizadora do tráfico europeu na África, que é apresentado como motivo apenas de fome, de dor, de horror (CLARKSON, 1823, p. 6-7).

\section{Escravo por natureza}

Na Antiguidade, na Idade Média e na Era Contemporânea, a produção escravista ensejou tendencialmente, em forma inexorável, a proposta da inferioridade natural do trabalhador escravizado, que se consolidou nas representações culturais e ideológicas sobre a natureza do escravizado produzidas pelo mundo dos escravizadores. No contexto do movimento histórico que transformou a África Negra no maior centro produtor de cativos conhecido até hoje pela história, consolidou-se fortemente as afirmações sobre a inferioridade natural do africano, em relação aos algozes. Processo que, por meio de múltiplas mediações, contribui ainda à sustentação do racismo antinegro contemporâneo.

A partir de meados do século $\mathrm{XV}$, a gênese, o desenvolvimento e a consolidação do tráfico e da escravidão negra ensejaram a retomada plena da visão aristotélica, parida pela antiguidade escravista, do cativeiro como destino de homens inferiores por natureza, necessariamente dirigidos por aqueles que lhe eram também naturalmente superiores (CARBONI; MAESTRI, 2006). Destino desejável para seus senhores e para 
eles mesmos, já que incapazes, por natureza, de se manterem em sociedade de forma autônoma e organizada.

\begin{abstract}
Segundo Aristoteles, a natureza criara as coisas diferentes, na procura da especialização, já que o melhor "instrumento" seria o que serve para "apenas" um "mister", e não para muitos. Assim, seres de essência diversa complementariam-se, cada qual desempenhando a função para que era criado, na consecução de fins que lhes eram comuns. Porém, a hierarquização desses seres obedecia a natureza. Assim sendo, os seres naturalmente mais elevados comandavam os objetivamente menos perfeitos. "A autoridade e a obediência não só são cousas necessárias, mas ainda [...] úteis. Alguns seres, ao nascer, se vêem destinados a obedecer; outros, a mandar" (MAESTRI, 2014, p. 150.).
\end{abstract}

A desqualificação do cativo negro-africano fora facilitada e apoiada pela cor mais escura da pele dos escravizados e pela diferença relativa das civilizações, sobretudo do litoral do Continente Negro, em relação à Europa. Na crítica da proposta da desigualdade e da hierarquização racial da espécie humana, o pensamento abolicionista teve que realizar um esforço hercúleo para se sobrepor aos prejuízos das concepções de mundo das classes hegemônicas.

\section{A visão dos oprimidos}

Ao interpretar as necessidades de importantíssimos segmentos das classes subalternizadas e oprimidas, o pensamento abolicionista contribuiu poderosamente para o desenvolvimento e o fortalecimento das visões unitaristas da sociedade humana, mais tarde plenamente confirmados pelas ciências sociais e naturais contemporâneas. Thomas Clarkson lembrava:

Os traficantes europeus conhecendo muito bem a sua culpa, e sabendo que as vozes da natureza haviam de bradar contra os seus crimes, tem-se precavido, há muitos tempos, com argumentos em sua defesa. [...] têm espalhado no público e continuam a espalhar que os africanos são criaturas doutras espécie; que não tem faculdades, nem os sentimentos de homens; que estão no mesmo nível dos brutos [...] (CLARKSON, 1823, p. 10-11).

A defesa de Clarkson da excelência da humanidade do africano baseia-se essencialmente no testemunho de viajantes desinteressados. Para tal, serviu-se abundantemente do depoimento de Mungo Park para afirmar o caráter moral, a rejeição da mentira, a afeição familiar, a hospitalidade, a ternura do africano. No mesmo sentido, o depoimento do médico escocês é abundantemente utilizado para reafirmar o caráter intelectual e o valor da produção autóctone do habitante da África Negra. Como vimos, o autor destacou-se igualmente pela apresentação e pela valorização da produção cultural material negro-africana.

A conclusão do autor era clara:

Temos mostrado que eles são gratos para com os seus benfeitores; que guardam fidelidade àqueles que os empregam; que amam a verdade; que possuem todos os sentimentos brandos e humanos de nossa natureza; que são capazes de conduzir o governo civil; que possuem cidades de grande comércio, rodeadas de um país bem cultivado; e que exercem não só os tratos e ofícios comuns e ordinários mais ainda aqueles para que se requer engenho e talento. 
Assim sendo, conclui:

Se pois os africanos possuem em comum com os europeus caráter moral e intelectual, quem haverá que se atreva a negar-lhes os direitos de homens a não serem os contratadores de escravos? (CLARKSON, 1823, p. 16).

\section{Reflexão exemplar}

A refutação da segunda grande prova dos negreiros sobre a inferioridade dos africanos, ou seja, eles não terem construído grandes civilizações, exigia conhecimentos que não se encontravam desenvolvidos e consolidados na época em que escrevia o autor de $O s$ gemidos dos africanos. Esse argumento constitui ainda um dos principais apoios das narrativas racistas antinegras atuais, devido ao caráter irretorquível desta prova, para o senso comum e o pensamento trivial. Já naquele então, os negreiros propunham, como confirmação de suas teses, "que apesar de haver séculos que se descobriu a África, os seus habitantes não têm feito progressos em civilização, como outros povos" (CLARKSON, 1823, p. 16).

A resposta de Clarkson registra o singular esforço racionalista desenvolvido pelo pensamento abolicionista da época, ao lançar mão criativamente do evolucionismo e comparativismo para dissolver o silogismo negreiro irracionalista. Inicialmente, o autor aponta diversas outras regiões e outros povos do globo terrestre, que não eram utilizados como sementeiras de cativos, no mesmo ou em estágio civilizatório inferior ao africano: os povos nativos da América; de Bornéus; de Sumatra, etc. (CLARKSON, 1823, p. 16). Mas, sobretudo, esforça-se em demonstrar que não há inferioridade natu- ral da civilização africana, nem mesmo em relação à Europa.

Clarkson lembra que a história demonstrava que o fato de uma nação civilizada alcançar superioridade deve-se essencialmente ao "aumento gradual de conhecimentos dentro de si mesma" e "à comunicação com outras mais ilustradas". Portanto, o comércio seria um grande vetor civilizatório. Desde que ele se desse, de parte a parte, com "espírito de equidade". Mais ainda, assinalava que o berço de todas as ciências seria o Egito, passando de lá as ciências para a Grécia e, por intermédio da pequena nação - então, "mais rude e bárbara do que a África" - para Roma e para o resto da Europa. E, em estocada terrível, Clarkson lembrava que o Egito civilizador fora habitado por povos de "caras negras e cabelo crespo" (CLARKSON, 1823, p. 17).

\section{Egito Negro}

Um argumento retomado, racionalizado e radicalizado, mais tarde, por Cheikh Anta Diop (1923-1986), com grande repercussão entre as filas do movimento nacionalista negro estadunidense. Para o célebre intelectual senegalês, o Egito seria uma civilização negra, nas suas raízes, não se tratando apenas de influências e de dinastia faraônica núbia, como comprovado pelas ciências históricas (DIOP, 1960, 1967, 1977, 1981).

A partir de critérios socio-históricos, Thomas Clarckson destaca o isolamento geográfico da África Negra em relação à circulação do conhecimento no passado e a baixíssima qualidade dos contatos propiciados 
por "negociantes de escravos", que define como verdadeiros "monstros".

A natureza das suas relações com a moderna Europa tem tendido constantemente a degradá-la e desmoralizá-la (a África); e em vez de lhe causarem benefício, $[\ldots]$ tem-lhe servido de maldição (CLARKSON, 1823, p. 18).

Tratava-se igualmente de uma poderosa refutação da proposta da expansão europeia, no geral, e britânica, em especial, como veículo civilizador das regiões atrasadas do mundo. Por esses anos, no interior da América do Sul, José Gaspar de Francia, ditador paraguaio pela vontade das classes plebeias, refletia sobre os malefícios para seu país das trocas desiguais ensejadas pelo livre-câmbio com as nações mais avançadas, com destaque para a Inglaterra.

Cuando la bandera de la República sea libre de navegar hasta el mar, se admitirá el que vengan a comercial y que entonces se arreglará el comercio según convenga, y de modo que se útil a los paraguayos y no sea solamente como hasta aquí para aprovechamiento y beneficio de los estraños (WHITE, 1989, p. 182).

Nos capítulos três e quarto, Clarkson dedica-se sobretudo a uma apresentação criteriosa da inumanidade da captura, do transporte até a costa e da travessia dos africanos escravizados, baseado nos documentos citados. Nesse relativo, uma grande atenção é dada ao estudo do navio negreiro, com base nas plantas e nos dados do navio Brookes, de 320 toneladas, que tinha licença para transportar 454 cativos, do qual anexa as plantas ao livro. Aborda o embarque, o armazenamento, as enfermidades, a resis- tência dos cativos, a mortalidade na travessia. A desumanidade propiciada pelo tráfico é exemplificada com alguns casos extremos de negreiros ingleses e franceses (CLARKSON, 1823, p. 37).

\section{0 direito dos homens}

Os dois capítulos derradeiros são dedicados à demolição final da argumentação justificadora dos negreiros. Para tal, retoma, inicialmente, o argumento já apresentado, séculos antes, pelo sacerdote, gramático, humanista e abolicionista português Fernando Oliveira, em 1535, sobre a "guerra justa" (MAESTRI, 2010). Thomas Clarkson lembrava que a prática da violência contra indivíduos que não causaram nenhum mal aos seus ofensores constitui uma clara "injustiça", "admitida por todos os que governam as nações civilizadas" (CLARKSON, 1823, p. 38).

Crime inaceitável, mesmo no caso em que se conviesse, para simples efeito de argumentação, que os cativos eram produzidos por violência endógena africana e os negreiros apenas se limitassem a comprá-los na costa. Agregava, igualmente, que outra "máxima" sobre a qual se apoiava o mundo civilizado era que o "recebedor dos furtos é tão criminoso como o ladrão". Ou seja, os negreiros seriam, no melhor dos casos, receptadores do produto de um roubo escancarado (CLARKSON, 1823, p. 39).

Agora não importa por qual destes axiomas queiramos julgar os traficantes europeus; se como recebedores de furtos ou autores dos males de que justamente nos queixamos. Estes males nunca teriam existido a não serem eles. 
"Se os traficantes de escravos nunca fossem à África, mui poucos dos seus habitantes haveria [sic] escravos" - fulmina o abolicionista. Assim, a sua conclusão é lógica:

Portanto, os europeus, ainda que eles não sejam os principais atores na funesta tragédia das misérias dos africanos que temos referido, são, não obstante, os autores de todas elas; e por consequência, o tráfico que eles fazem e fomentam não pode considerar-se senão como uma grande violação dos princípios de justiça reconhecidos por todas as nações civilizadas (CLARKSON, 1823, p. 40).

$\mathrm{O}$ autor fulmina igualmente o velho argumento de que o africano viveria melhor como escravo na América, do que no Continente Negro, "porque no primeiro caso, trabalha debaixo do poder de um senhor civilizado e, no segundo, em poder de um bárbaro" (CLARKSON, 1823, p. 42). Argumento que teve longa vida no Brasil escravista e se projetou nos séculos XX e XXI, celebrizado por obras como as de Gilberto Freyre e seus epígonos atuais (MAESTRI, 2004).

\section{Servidão africana, escravidão americana}

Mais uma vez, sua crítica é irrefutável. Inicialmente, Clarkson lembra que era reduzido o número de africanos reduzidos ao cativeiro na África. E, a seguir, assinala, com absoluta pertinência, a suavidade da servidão costumeira africana em relação à desapiedada escravidão colonial americana:

[...] a escravidão em África é comparativamente uma condição livre e folgada; é uma espécie de vassalagem patriarcal, e em muitos respeitos preferível à que por muitos séculos subsistiu na Europa (CLARKSON, 1823, p. 42).
Apoiado em Mungo Park, Thomas Clarkson lembra que o cativo africano não podia ser vendido ao bel prazer por seu patriarca, que eles viviam e comiam "juntamente com seus donos", trabalhando "juntos, seja no campo ou em casa, sem nenhuma distinção aparente". E, sobretudo, apresenta a terrível degradação das condições de vida conhecida pelo africano ao ser escravizado na América:

Suponhamos porém que o caso era diferente; e suponhamos que, nem os donos, nem os feitores, eram homens endurecidos por hábitos de crueldade, mas sim homens de sentimentos ordinários. Pois mesmo assim a escravidão na África seria para os escravos um paraíso, comparada com a escravidão nas colônias (CLARKSON, 1823, p. 43).

Ao diferenciar qualitativamente escravidão americana e servidão africana, Thomas Clarkson descrevia a realidade devida às exigências necessárias impostas, nos seus marcos gerais, pelas formas de produzir e não nascida dos sentimentos dos proprietários europeus ou senhores africanos dos cativos. A escravidão colonial americana tinha seus ritmos de produção e condições de trabalho impostos pelas exigências de produção mercantil, abastecendo o mercado internacional. A servidão africana realizava-se no contexto de economia voltada para o abastecimento do núcleo doméstico (MAESTRI, 1986, p. 66-88).

O missionário italiano João Antônio Cavazzi, natural de Montecuccolo, na Itália, aportou em Luanda, em novembro de 1654, permanecendo por treze anos em territórios da atual Angola. Em registro da diferença entre a servidão africana e a escravidão colonial, ele observou, perplexo, em seu célebre relato sobre essas regiões: 
No reino do Congo, o número de escravos é quase igual ao de pessoas livres. Há, porém, grande diferença entre os escravos dos portugueses e os dos pretos. Os primeiros obedecem não só às palavras, mas até aos sinais, receando sobretudo ser levados para o Brasil. [...] Os escravos dos pretos são obstinados, insubordinados [...] (CAVAZZI, 1965, p. 31).

\section{Destino terrivel}

O peso do cativeiro sobre o africano reduzido à escravidão nas Américas, um estranho em terra estranha, não escapa a Thomas Clarkson:

A própria cor, a linguagem, as feições, tudo conspira a fazer-lhes lembrar a todos os momentos a inferioridade da sua situação. Quando estavam no seu país, viviam com seus senhores, criaturas da mesma espécie e da mesma aparência que eles. Podiam falar, e serem entendidos; queixar-se e serem ouvidos.

Portanto, a terrível diatribe do abolicionista inglês inverte a justificativa dos escravistas, ao proporem que a vida na África, em qualquer situação, era preferível à vida na América, como trabalhador escravizado (CLARKSON, 1823, p. 43).

O sexto e último capítulo é dedicado ao então maior argumento dos negreiros em prol do tráfico - o fato de que o africano pagão arrancado da África tornava-se cristão na América, pagando assim, com o cativeiro transitório do corpo a eterna soltura da alma. Essa justificativa fora apresentada pelo cronista real Gomes Eanes de Zurara (c.1410-1474), quando comentava a chegada dos primeiros negro-africanos a Lagos, no Algarves, no início do tráfico de africanos para Portugal.
[...] somente uma santa intenção (do príncipe dom Henrique) que havias de buscar salvação para as almas perdidas, [...], ainda que a força do maior bem era deles mesmo, que posto que seus corpos estivessem em algum sujeição, isto era pequena cousa em comparação das suas almas, que eternamente haviam de possuir verdadeira soltura (ZURARA, 1973, p. 80).

Thomas Clarkson aborda a questão a partir da proposta da "repugnância" original da Igreja Primitiva à escravidão que levaria as "pessoas que morriam" a "forrarem seus escravos". Para ele, a alteração positiva do estado da Europa de sua época em relação ao passado e ao fato de as primeiras nações cristianizadas terem sido formadas essencialmente por homens livres deveriam-se a essa "benigna influência da religião cristã" (CLARKSON, 1823, p. 45). Segundo o autor, para contornar essa realidade, os negreiros justificavam o tráfico infame sob a escusa de que

[...] suas expedições contribuíam para o bem da religião e promoviam a pregação do cristianismo entre os gentios da África além dos que levavam para as colônias para lá se converterem (CLARKSON, 1823, p. 46).

Clarkson propõe que não se convertera africano algum na África, e que os negreiros eram, de fato, empecilhos à cristianização.

Para ele, a própria escravidão incompatibilizaria o escravizado com o cristianismo. O trabalhador escravizado faminto era levado ao furto. O trabalho excessivo e o castigo eram contraditórios com a lealdade e a submissão voluntária (CLARKSON, 1823, p. 47). Para ele, o exemplo era mais eficaz do que o preceito. 
Cada senhor é um monarca nas suas terras. Ali podem eles exercitar as suas paixões ou as suas iras sem moderação nem limites, nem receio algum de punição (CLARKSON, 1823, p. 48).

Mas, sobretudo, lembrava Clarkson que, mesmo no caso em que todos os africanos se convertessem ao cristianismo, isso não lhes serviria de desculpa das guerras, dos roubos, das mortes e devastações que se faziam na:

África por causa deles (os negreiros); nem das misérias e das mortandades que tem lugar nas viagens, por causa deles. Por todos estes crimes ainda eles seriam responsáveis; e o tráfico da escravatura nem por isso cessaria de ser uma violação monstruosa do espírito, como da letra da religião revelada; nem poderia deixar de o ser, enquanto ele continuasse a ser fundado em crimes (CLARKSON, 1823, p. 48).

\section{A Bíblia contra a escravidão}

Thomas Clarkson busca na Bíblia a impugnação do relativismo moral e social escravista. Segundo ele, São Paulo era claro na carta aos Coríntios: "Não devemos fazer mal para que nos venha bem" (CLARKSON, 1823 , p. 48). E o tráfico era morte, era roubo, era a cobiça do bem do próximo, contra a Lei Moral de Moisés. Uma realidade que, segundo o Êxodo, deixaria o negreiro em uma péssima situação: “Aquele que furtar um homem e o vender para escravo, convencido que for deste crime, morra".

As consequências da exegese da Bíblia eram cabais:
O tráfico da escravatura já se vê que está condenado pelo Velho e Novo Testamento, se bem interpretamos as passagens citadas. Agora, se nestes livros, e só nestes, se contém a vontade de Deus, como foi manifestada aos homens, então podemos dizer que está provada a proposição que avançamos no princípio deste capítulo; que o tráfico da escravatura é oposto aos princípios da moral e da justiça estabelecidos entre as gentes civilizadas; e que o é, igualmente, aos princípios da religião revelada (CLARKSON, 1823, p. 51).

Tratava-se de uma visão, temos que reconhecer, bastante seletiva e utilitarista das posições e ensinamentos do Antigo e do Novo Testamento e da Igreja em relação à escravidão. No Antigo Testamento e nas palavras de Jesus e dos apóstolos, não houve condenação da escravidão como instituição, mas aceitação. Uma posição radicalizada quando o cristianismo, após assumir sua orientação universalista, transformou-se em religião de Estado, no fim do Império Romano e nos séculos posteriores. Desde então, a Igreja defendeu e racionalizou a ordem e a submissão escravistas (MAESTRI, 2014, p. 147-170).

A apresentação da gravura do tumbeiro inglês não constituía uma simples ilustração do ensaio, já que Clarkson possuía plena consciência do poder da imagem no convencimento. Ao dirigir-se diretamente ao leitor, recomenda:

[...] particular atenção à estampa do navio de escravatura que vai anexa a um dos capítulos a qual por si só fala volumes. Ela vos excitará a lembrança das angústias e tormentos que padecem os miseráveis negros sobre o oceano; e com o socorro da imaginação, vos fará lembrar igualmente das cruezas e aflições que os mesmos têm padecido no seu próprio país donde partiram, e ainda vão padecer nos alheios, para onde os destinam (CLARKSON, 1823, p. 51). 
Esforçava-se, assim, para que o leitor, mesmo em forma involuntária, se colocasse, no geral e no particular, na posição do cativo, entulhado nos porões escuros e fétidos dos navios negreiros, durante a longa e dolorosa travessia. Por meio de sua démarche de forte cunho empírico, Thomas Clarkson apresentou aos seus leitores panoramas de profundo sentido objetivo sobre a experiência negreira. Suas descrições abordavam e desvelavam nexos essenciais das tendências profundas do tráfico de cativos e das apologias construídas em sua defesa. Nesse processo, antecipava, como proposto, no geral, as conclusões obtidas pela moderna historiografia especializada, mais de um século após sua investigação. Provava que, também nesse caso, ontem como hoje, não se via e não se compreendia, por que simplesmente não se queria ver e compreender.

\section{Abstract}

Upon completion of his higher education, the Britishman Thomas Clarkson decided to dedicate his life to the denunciation and fight for the abolition of Africans enslaved trafficking by United Kingdom. In its anti-trafficking campaign, he stood by undertaking a vast research with the sailors, British doctors, etc. dedicated to that trade. Author of a vast bibliography on the subject, presented in a booklet translated to Portuguese in 1823 a powerful critique of the slave trade, anticipating contemporary historiographical achievements on it. This article analyzes this cause celèbre.

Keywords: Slave trade. Abolicionism. Black Africa.

\section{Resumen}

Al concluir sus estudios superiores, el inglés Thomas Clarkson decidió dedicar su vida a la denuncia y la lucha por la abolición de la trata de esclavos africanos por la Inglaterra. En su campaña contra la trata, el se destacó por la realización de una vasta investigación junto a los marineros, médicos ingleses, etc. dedicados a ese comercio. Autor de una vasta bibliografía sobre el tema, presentó en el folleto traducido al portugués en 1823 una poderosa crítica de la trata de esclavos, anticipando logros historiográficas contemporáneas en él. En este artículo se analiza esta su famosa denuncia.

Palabras clave: Tráfico esclavista. Abolicionismo. África Negra.

\section{Nota}

1 Cf. texto em inglês disponível em: <http:/ / www. recoveredhistories.org/browse.php $>$.

\section{Referências}

ANDRADA E SILVA, José Bonifácio. 17631838. Representação à Assembléia Geral Constituinte e Legislativa do Império do Brasil sobre a escravatura. Paris: Firmin Didot, 1825.

BETHELL, Leslie. A abolição do tráfico de escravos no Brasil: A Grã-Bretanha, o Brasil e a questão do tráfico de escravos (1807-1869). Tradução de V. N. N. Pedroso. Rio de Janeiro: Expressão e Cultura; São Paulo, Ed. da Universidade de São Paulo, 1976.

CANOT, Teodoro. Memórias de un tratante de esclavos. Buenos Aires: Cronos, 1947. 
CAPELA, José. Escravatura: a empresa de saque, o abolicionismo (1810-1875). Porto: Afrontamento, 1974.

Escravatura: Conceitos a empresa de saque. 2. ed. rev. Porto: Afrontamento, 1978.

CARBONI, Florence; MAESTRI, Mário. A linguagem escravizada. História, poder, luta de classes. 2. ed. rev. e ampl. São Paulo: Expressão Popular, 2006.

CAVAZZI DE MONTECÚCCOLO, Pe. João António. Descrição histórica dos três reinos do Congo, Matamba e Angola. Tradução, notas e índices do Pe. Graciano Maria de Leguzzano. Lisboa: Junta de Investigações do Ultramar, 1965. 2 vols.

CLARKSON, A M. Thomas. Os gemidos dos africanos, por causa do tráfico da escravatura: breve exposição das injúrias e dos horrores que acompanham este tráfico homicida. Londres: Harvey e Darton, 1823.

CONRAD, Robert Edgar. Tumbeiros: o tráfico escravista para o Brasil. São Paulo: Brasiliense, 1985.

CRUMMEY, Donald; STEWART, C. C. (Ed.). Modes of production in África. The Precolonial Era. London: Sage, 1981.

DA COSTA, Emília Viotti. Da senzala à colônia. 2. ed. São Paulo: Ciências Humanas, 1982.

DIOP, Cheikh Anta. L'unité culturelle de l'Afrique Noire. Paris: Présence Africaine, 1960.

. Antériorité des civilisations nègres: mythes ou vérité historique? Paris: Présence Africaine, 1967.

Parenté génétique de l'égyptien pharaonique et les langues négro - africaines. Dakar: Nouvelles Editions Africaines, 1977.

. Civilisation ou barbarie. Paris: Présence Africaine, 1981.

GODELIER, Maurice. Sobre as sociedades pré-capitalistas. Lisboa: Seara Nova, 1976.
GOULART, Maurício. Escravidão africana no Brasil: das origens à extinção do tráfico. 3. ed. São Paulo: Alfa-Ômega, 1975.

KARASCH, Mary C. A vida dos escravos no Rio de Janeiro (1808-1850). São Paulo: Companhia das Letras, 2000.

LOVEJOY, Paul E. Transformations in slavery. A history of slavery in Africa. Cambridge: Cambrigde University, 1983.

MACEDO, José Rivair. História da África. São Paulo: Contexto, 2013.

MAESTRI, Mário. A agricultura africana nos séculos XVI e XVII no litoral angolano. Porto Alegre: Editora da Universidade Federal do Rio Grande do Sul, 1978.

A Igreja e a escravidão na Antiguidade e na Idade Média. In: PINHEIRO, Á. da P.; FALCI, M. B.; LIMA, S. O. (Org.). Patrimônio e cultura negra. Parnaiba: Vox Musei, 2014. p. 171-190.

. Breve história da escravidão. Porto Alegre: Mercado Aberto, 1986.

Fernão de Oliveira: o cristão-velho abolicionista: a repressão ao pensamento racional e abolicionista em Portugal do século 16. Revista Estudios Digital, número especial, otoño 2010. Centro de Estudios Avanzados de la Universidad Nacional de Córdoba, Cordoba, v.1, 2010. Disponível em: <http://www.revistaestudios.unc.edu.ar/articulos03/articulos/4maestri.php>. Acesso em: 10 maio 2011.

. Mungo Park vai à África. Temas de História, Rio de Janeiro, Universidade de Santa Úrsula, v. 1, n. 1, p. 59-64, 1983.

. O escravismo no Brasil. 10. ed. São Paulo: Atual, 2002.

Os senhores do litoral: conquista portuguesa e agonia tupinambá no litoral brasílico: século XVI. 3. ed. Porto Alegre: EDUFRGS, 2013.

MARQUES, João Pedro. Os sons do silêncio: o Portugal de Oitocentos e a abolição do tráfico 
de escravos. Lisboa: Imprensa de Ciências Sociais, 1999.

MEILLASSOUX, Claude. L'esclavage en Afrique précoloniale: dix-sept études présentées par. Paris: François Maspero, 1975.

Mulheres, celeiros $\mathcal{E}$ capitais. Porto: Afrontamento, 1977.

MENDES, Luiz Antônio de Oliveira. Memória a respeitos dos escravos e tráfico da escravatura entre a costa d'África e o Brasil. Porto: Publicações Escorpião, 1977. (1793).

MIERS, Suzanne; KOPYTOFF, Igor. Slavery in Africa: historical and anthropological perspectives. Wisconsin: University of Wisconsin, 1977.

PARK, Mungo. Voyage dans l'intérieur de l'Afrique. Paris: Maspero, 1980.

PÉTRÉ-GRENOUILLEAU, Olivier. Les traites négrières: essai d'histoire globale. Paris: Gallimard, 2004.

PINHEIRO, Área da Paz; FALCI, Miridan Britto; LIMA, Solimar Oliveira. (Org.). Patrimônio e cultura negra. Teresina: VOX MUSEI arte + patrimônio, 2014.

RENAULT, François; DAGET, Serge. Les traites négrières en Afrique. Paris: Karthala, 1985.

REDIKER, Marcus. O navio negreiro: uma história humana. São Paulo: Companhia das Letras, 2011.

ROCHA, Manoel Ribeiro. Etíope resgatado: empenhado, sustentado, corrigido, instruído e libertado. Discurso sobre a libertação dos escravos no Brasil de 1758. Petrópolis: Vozes; São Paulo: Cehila, 1992.

RODRIGUES, Jaime. De costa a costa: escravos, marinheiros e intermediários do tráfico negreiro de Angola ao Rio de Janeiro (1780-1860). São Paulo: Companhia de Letras, 2005.

STEIN, Stanley J. A grandeza e decadência do café no Vale do Paraíba. Com referência especial ao município de Vassouras. São Paulo: Brasiliense, 1961.

VANSINA, Jan. Les anciens royaumes de la savane. Léopoldville: Institut de Recherches Economiques et Sociales, 1965.

VASSA, Gustavus. The Interesting narrative of the life of Olaudah Equiano, or Gustavus Vassa, the African. Written by himself. London: Author, 1789. WHITE, Richard Alan. La primera revolución popular en America: Paraguay (1810-1840). 2. ed. Asunción: Carlos Schauman, 1989.

WILSON, Ellen Gibson. Thomas Clarkson: a biography. $2^{\text {nd }}$ ed. New York: William Sessions, 1996.

ZURARA, Gomes Eanes da. Crônicas de Guiné. Segundo o MS. De Paris. Modernizada. Introdução, notas, novas considerações e glossário de José de Bragança. (Ed. de 1937.) Lisboa: Civilização, 1973. 